\title{
ISOLATION OF BIOACTIVE COMPOUND OF MICHELIA CHAMPACA L. BARK AND ITS ACTIVITY TEST USING MECHANISM-BASED YEAST BIOASSAY
}

\author{
ADE ZUHROTUN ${ }^{1,2 *}$, ASEP GANA SUGANDA ${ }^{2}$, KOMAR RUSLAN WIRASUTISNA $^{2}$, MARLIA SINGGIH WIBOWO ${ }^{3}$
}

${ }^{1}$ Department of Pharmaceutical Biology, Faculty of Pharmacy, Universitas Padjadjaran, Jl Raya Bandung-Sumedang KM 21, 5 Jatinangor 45363, West Java, Indonesia. ²Department of Pharmaceutical Biology, School of Pharmacy, Institut Teknologi Bandung, Jl Ganeca No. 10 Bandung 40132, West Java, Indonesia. ${ }^{3}$ Department of Pharmacochemistry, School of Pharmacy Institut Teknologi Bandung, Jl Ganeca No 10 Bandung 40132 West Java Indonesia Email: airkusaja@yahoo.com

Received: 14 May 2016, Revised and Accepted: 25 May 2016

\section{ABSTRACT}

Objectives: This study aimed to isolate the active compound of Michelia champaca L. bark and test its activity using mechanism-based yeast bioassay.

Methods: The bark was extracted by methanol; fractionation was done by liquid-liquid extraction (LLE) using n-hexane, ethyl acetate, and water. The activity of LLE fractions was tested by mechanism-based yeast bioassay. The most active fraction was then separated by vacuum liquid chromatography, further separated by classical column chromatography and purified by recrystallization. The isolate was characterized by ultraviolet-visible, infrared spectrophotometric method, nuclear magnetic resonance spectroscopy, and mass spectrometric method.

Results: The isolation process resulted in an isolate named MCET51. Characterization data showed that $\mathrm{MCET} 1$ was proved as liriodenine $\left(\mathrm{C}_{17} \mathrm{H}_{9} \mathrm{NO}_{3}\right)$ with molecular weight $275(\mathrm{~m} / \mathrm{z})$, an aporphine alkaloid. The activity assay showed that liriodenine was active against Saccharomyces cerevisiae strain 1140,1353 , and 1138 with $\mathrm{IC}_{12}$ values were $22.15 \pm 1.71,24.76 \pm 0.56$, and $7.02 \pm 1.85 \mu \mathrm{g} / \mathrm{ml}$, respectively.

Conclusions: It can be concluded that M. champaca L. bark contained liriodenine which was active both as topoisomerase I inhibitor and topoisomerase II inhibitor.

Keywords: Michelia champaca L., Topoisomerase inhibitor, Mechanism-based yeast bioassay, Liriodenine.

(C) 2016 The Authors. Published by Innovare Academic Sciences Pvt Ltd. This is an open access article under the CC BY license (http://creativecommons. org/licenses/by/4. 0/) DOI: http://dx.doi.org/10.22159/ajpcr.2016.v9i5.12856

\section{INTRODUCTION}

Michelia champaca L. or Cempaka kuning is a tree with $15-25 \mathrm{~m}$ high grown in Java area in Indonesia, at $1200 \mathrm{~m}$ altitude marshy forest. This species is a member of Magnoliaceae that usually produces proanthocyanidins and alkaloid, often cyanogenic compounds and volatile oil. Traditional usage of bark is for tonicum, herbal maternity, and curing fever $[1,2]$.

M. champaca bark was active against Aspergillus versicolor, Trichophyton tronsurum, Aspergillus niger, and Aspergillus vitis [3] and against human epidermoid carcinoma of the nasopharynx [4]. The leaves were active as an anti-inflammatory [5], antiarthritic [6], and antifertility [7] Michelia flower was active as burn wound healing [8], antioxidant [9], anti-inflammatory [10], antihyperlipidemic [11], and anticancer on Ehrlich ascites carcinoma cell line [12]. In addition, the flower and leaves of Michelia were having antiulcerogenic property [13].

Chemical compounds contained in C. kuning were sinapyl 4-0- $\beta$ D-glucopyranoside alcohol, sinapyl 4-0- $\beta$-D-glucopyranoside aldehyde, syringaresinol and $N$-acetylnonaine [14], michampanolide, 8-acetoxyparthenolide, magnograndiolide, parthenolide, cestunolide [15], quercetin [16], champacaine, anonaine, norushinsunine, ushinsunine, $\mathrm{N}$-acetylanonaine, roemerine, asimilobine, anolobine, isocorydine, liriodenine, atherospermidine, 0-methyl moschatoline, syringaresinol, N-trans-feruloyltyramine, 4-hydroxybenzaldehyde, vanillin, vanillic acid, syringic acid, 3,4-dimethoxybenzoic acid, coniferyl aldehyde, syringin, scopoletin, 4-acetonyl-3,5-dimethoxy-p-quinol, sitostenone, stigmasta-4,22-dien-3-one [17], stigmasterol and $3 \beta-16 \alpha-$ dihydroxy-5-cholestene-21-al, Michelia-A, and guaianolides [4].

DNA topoisomerases is an important enzyme in cell proliferation phase of developing cancer in all types. Anticancer targeting this enzyme will alter the process of DNA replication and transcription so that inhibit cell division and inactivate cancerous cells from growing and dividing [18].
Mechanism of drug targeting this enzyme and biological roles of DNA topoisomerase can be studied in yeast, as powerful model system [19] because of its genetic and biochemical of yeast resemblances is close to mammalian cells [20]. Hence, microbial yeast bioassay is suitable for evaluating or screening anticancer agents.

In previous research, 23 species of Apocynaceae, Simaroubaceae, and Magnoliaceae have been screened for their anticancer activity, and $M$. champaca L. bark was one of the best active extracts against Saccharomyces cerevisiae strain 1140, 1353, and 1138 with IC $_{12}$ values were $3424.54 \pm 2806.57,2124.42 \pm 450.40$, and $542.6 \pm 102.45 \mu \mathrm{g} / \mathrm{ml}$, respectively. The results mean that M. champaca extract active as anticancer, having DNA damaging agent or topoisomerase inhibitor [21]. However, the active ingredients that corresponded with the activity were still unknown. So, this present study aimed to isolate the active compound of $M$. champaca L. bark guided by mechanism-based yeast bioassay.

\section{METHODS}

\section{Materials}

C. kuning bark, methanol, ethanol, aquadest, n-hexane, chloroform, ethyl acetate, dimethyl sulfoxide, precoated plate silica gel $\mathrm{GF}_{254}$, silica gel $\mathrm{H}$, silica gel 60 (0.063-0.200 mm), agar bacteriological, peptone, dextrose, yeast extract, and sodium chloride.

\section{Instruments and apparatus}

Grinder, macerator, rotavapor(Buchi), electric dryer(Philips), separatory funnel, freeze dryer (Telstar), vacuum column chromatography, classical column chromatography, common glassware in laboratory, ultraviolet (UV) lamp (Desaga), UV-visible spectrophotometer (HP 8453), thin-layer chromatography (TLC) densitometer (Camag), infrared spectrophotometer (FT/IR Jasco 4200), mass spectrometry (waters), and nuclear magnetic resonantion spectrometry (Agilent $500 \mathrm{MHz}$ ). 
Sample preparation

M. champaca L. bark was collected on January 2015 from area of Institut Teknologi Bandung (ITB) West Java Indonesia. Fresh bark was sorted, chopped in small pieces, air-dried in drying cupboard $\left(40^{\circ} \mathrm{C}\right)$ for $24 \mathrm{hrs}$. Plant sample (collection no 12.130) was authentication in Herbarium Bandungense, School of Life Sciences and Technology ITB.

\section{Extraction and fractionation}

Extraction of dried bark was done by methanol maceration for $24 \mathrm{hrs}$ in three replication, and the filtrate was concentrated using vacuum rotary vaporator. Condensed extract was fractionated by liquid-liquid extraction (LLE) using n-hexane followed by ethyl acetate and water. All fractions of LLE were tested for their activity using mechanism-based yeast bioassay against $S$. cerevisiae strain 1140,1353, and 1138 .

\section{Activity test using mechanism-based yeast bioassay}

The method mechanism-based yeast bioassay was done according to Gunatilaka and Kingston [20], Gunatilaka et al. [22], Subong and Primavera [23] as modified by Zuhrotun et al. [21] as followed. Saccharomyces cerevisiae strains 1140, 1353, and 1138 that cultured in yeast peptone dextrose (YPD) broth was suspended in sterile $0.9 \%$ saline solution until the transmitant was $80 \%$ at $1600 \mathrm{~nm}$. Yeast inoculums $1 \mathrm{ml}$ and medium YPD agar $20 \mathrm{ml}$ were poured into a petri dish with $9 \mathrm{~cm}$ diameter that produced $6 \mathrm{~mm}$ layer. Seven wells with $6 \mathrm{~mm}$ diameter were made on the plate using perforator. Samples were dissolved in a mixture of dimethyl sulfoxide-methanol (1:1) with variation concentrations. Amount of $50 \mu \mathrm{l}$ of the mixture was placed in each well. The plates were then incubated at $30^{\circ} \mathrm{C}$ for 36-48 hrs. The samples were considered active or contain DNA damaging agent if inhibition zone produced as the growth of yeast were inhibited. $\mathrm{IC}_{12}$ value was referred to required concentration of sample (in $\mu \mathrm{g} / \mathrm{ml}$ ) that produced an inhibition zone of $12 \mathrm{~mm}$ around a well. The value was determined using linear regression from doseresponse curves with log of dose as absis (Y) and zone size as ordinate (X). A topoisomerase I inhibitor defined to sample that active against S. cerevisiae strain 1140 and A topoisomerase II inhibitor defined to sample that active against S. cerevisiae strain 1353.

\section{TLC bioautography}

To guide isolation of active compound, the active fractions were tested by TLC bioautography $[24,25]$ with modification. Chromatography profile was performed by mixture of chloroform-methanol (9:1) as mobile phase and precoated plate silica gel $\mathrm{GF}_{254}$ as stationary phase. TLC plate was contacted on agar medium inoculated with the yeast for 15 minutes. After that, the plate removed and agar medium was incubated for 36-48 hrs, and inhibition zones were measured.

\section{Further separation and purification}

The active fraction $(10.21 \mathrm{~g})$ was separated using silica gel $\mathrm{H}$ by vacuum liquid chromatography with isocratic elution using n-hexaneethyl acetate (1:9) resulted 34 fractions. Fractions 16-31 (0.98 g) were further separated by open-column chromatography using silica gel 60 with isocratic elution of ethyl acetate-ethanol (10:1) resulted 72 subfractions. Subfractions $18-26(0.27 \mathrm{~g})$ were subjected to open-column chromatography again with same conditions resulted in 53 subfractions. Every fraction was monitored by TLC. The last, subfractions 7-18 purified by recrystallization using chloroformmethanol (9:1) and obtained yellow crystal-needle isolate $(30.2 \mathrm{mg})$ named MCET51.

The purity of MCET51 was tested by TLC using 3 mobile phases and two-dimensional (2D) TLC. The chromatography performed with commercial precoated plate silica gel $\mathrm{GF}_{254}$ as solid phase and mixture of ethyl acetate-ethanol (10:1), ethyl acetate-chloroform (6:4), and chloroform-methanol (9:1) as mobile phase.

\section{Characterization of isolate}

Characterization of MCET51 was done by color test, UV-visible, infrared spectrophotometric method, mass spectrometric method and nuclear magnetic resonance (NMR) spectroscopy of proton $\left({ }^{1} \mathrm{H}\right)$, carbon $\left({ }^{13} \mathrm{C}\right)$, Heteronuclear Single Quantum Coherence and heteronuclear multiplebond correlation spectroscopy.

\section{RESULTS AND DISCUSSION}

The yield of extraction was $5.82 \%(w / w)$. Since M. champaca bark extract was reported active with the method [21], then it directly fractionated by LLE obtained n-hexane, ethyl acetate, and water fractions. All fractions were tested by mechanism-based yeast bioassay to $S$. cerevisiae strains 1140,1353 , and 1138 . Activity results of fractions were shown in Table 1.

Fractions and pure compounds were considered active if IC $_{12}$ values at the lower doses of the extract, where the active extract ranging from 1000 to $8000 \mu \mathrm{g} / \mathrm{ml}$ [20]. Table 1 showed that all fractions were active against $S$. cerevisiae strain 1353 and 1138 with $\mathrm{IC}_{12}$ values $<8000 \mu \mathrm{g} / \mathrm{ml}$ and $\mathrm{n}$-hexane fraction also active against $S$. cerevisiae strain 1140 . These results indicated that the fractions contain active compound as topoisomerase inhibitor.

TLC bioautography is a combination of TLC as simple separation technique and antimicrobial bioassay. In this research, TLC was used to separated quickly the mixture of compounds contained in LLE fractions so that can be readily tested the biological activity of each component (spot). The result of TLC bioautography showed that the Rf of the active compounds were $0.8-0.84$ of ethyl acetate fraction and $0.69-0.74$ of n-hexane fraction.

According to TLC bioautography results, further separation and purification were focus on the active spot in ethyl acetate fraction. The process was yielded yellow crystal-needle isolate named MCET51. Purity tests showed MCET51 was a single spot with an area under curve $95.25 \%$ at $200-700 \mathrm{~nm}$. The isolate had a melting point at $271.5-272.6^{\circ} \mathrm{C}$.

The MCET51 gave yellow-red with Dragendorff reagent indicated that was alkaloid. UV-vis spectrum showed peaks absorbance at 205, 248, 268,309 , and $414 \mathrm{~nm}$ in methanol that predicted MCET51 was identical to aporphine alkaloid $[17,26]$. Infrared spectrum showed existence functional group of amines at $3421.1 / \mathrm{cm}, \mathrm{C}-\mathrm{H}$ stretch at $3039.26 / \mathrm{cm}$ and $2919.7 / \mathrm{cm}$, carbon aromatic at 1658.48, 1573.63; 1473.35 and $1419.35 / \mathrm{cm}$, and carbonyl at $1307.5 / \mathrm{cm}$ [27]. Mass spectrum showed $100 \%$ peak ion $[\mathrm{M}+1]^{+} 276.14(\mathrm{~m} / \mathrm{z})$, mean that molecular weight of MCET51 was $275(\mathrm{~m} / \mathrm{z})$.

NMR spectrum signals of MCET51 in $\mathrm{CDCl}_{3}$ showed the number of proton and carbon with their $2 \mathrm{D}$ correlation in determining structural arrangement [27] as shown in Table 2. These spectrum signals were identical with liriodenine based on previous results $[26,28,14]$. Based on characterization, data showed that MCET51 was proved as liriodenine, an aporphine alkaloid with molecular formula was $\mathrm{C}_{17} \mathrm{H}_{9} \mathrm{NO}_{3}$.

The result of activity assay of isolate showed that liriodenine was active against $S$. cerevisiae strain $1140\left(\mathrm{IC}_{12} 22.15 \pm 1.71 \mu \mathrm{g} / \mathrm{ml}\right)$, strain

Table 1: The IC ${ }_{12}$ values $(\mu \mathrm{g} / \mathrm{ml})$ of fractions as results of activity test using mechanism-based yeast bioassay

\begin{tabular}{llll}
\hline \multirow{2}{*}{ Sample } & \multicolumn{3}{l}{ S. cerevisiae strain } \\
\cline { 2 - 4 } & $\mathbf{1 1 4 0}$ & $\mathbf{1 3 5 3}$ & $\mathbf{1 1 3 8}$ \\
\hline $\begin{array}{l}\text { n-hexane } \\
\text { fraction }\end{array}$ & $1386.55 \pm 226.57$ & $111.18 \pm 43.09$ & $136.77 \pm 30.29$ \\
$\begin{array}{l}\text { Ethyl acetate } \\
\text { fraction }\end{array}$ & $>8000$ & $542.60 \pm 102.46$ & $279.43 \pm 163.07$ \\
$\begin{array}{l}\text { Water } \\
\text { fratio }\end{array}$ & $>8000$ & $401.62 \pm 107.40$ & $242.71 \pm 30.27$
\end{tabular}

fraction

S. cerevisiae: Saccharomyces cerevisiae 
Table 2: NMR spectrum signals of MCET51 and liriodenine ( $\delta$ in ppm, $\mathrm{J}$ in $\mathrm{Hz}$ )

\begin{tabular}{|c|c|c|c|c|c|c|}
\hline \multirow[t]{3}{*}{ No atom } & \multicolumn{2}{|c|}{ MCET51 } & \multicolumn{2}{|c|}{ Liriodenine [24] } & \multicolumn{2}{|c|}{ Liriodenine [26] } \\
\hline & C & $\mathbf{H}$ & C & $\mathbf{H}$ & C & $\mathbf{H}$ \\
\hline & 102.44 & $6.36(2 \mathrm{H}, \mathrm{s})$ & & $6.39(2 \mathrm{H}, \mathrm{s})$ & 102.4 & $6.35\left(2 \mathrm{H}, \mathrm{s}, \mathrm{O}-\mathrm{CH}_{2}-\mathrm{O}\right)$ \\
\hline 1 & 151.71 & & 144.54 & & 151.7 & \\
\hline $1 \mathrm{a}$ & 108.10 & & 107.76 & & & \\
\hline $1 \mathrm{~b}$ & 123.20 & & & & 123.2 & \\
\hline 2 & 147.90 & & 151.28 & & 148.8 & \\
\hline $3 a$ & 135.69 & & & & 135.7 & \\
\hline 4 & 124.21 & $7.73(1 \mathrm{H}, \mathrm{d}, \mathrm{J}=6.16)$ & 122.60 & $7.79(1 \mathrm{H}, \mathrm{d}, \mathrm{J}=5.19)$ & 124.2 & $7.73(1 \mathrm{H}, \mathrm{d}, \mathrm{J}=5)$ \\
\hline 5 & 144.90 & $8.86(1 \mathrm{H}, \mathrm{d}, \mathrm{J}=5.15)$ & 135.16 & $8.90(1 \mathrm{H}, \mathrm{d}, \mathrm{J}=5.4)$ & 144.9 & $8.86(1 \mathrm{H}, \mathrm{d}, \mathrm{J}=5.5)$ \\
\hline $6 a$ & 145.90 & & 144.15 & & 145.2 & \\
\hline 7 & 182.42 & & 181.8 & & 182.4 & \\
\hline $7 \mathrm{a}$ & 131.28 & & 123.86 & & 131.5 & \\
\hline 8 & 128.78 & $8.56(1 \mathrm{H}, \mathrm{d}, \mathrm{J}=8)$ & 127.57 & $8.59(1 \mathrm{H}, \mathrm{dd}, \mathrm{J}=7.95,0.9)$ & 127.3 & $8.60(1 \mathrm{H}, \mathrm{d}, \mathrm{J}=8.0)$ or $8.56(1 \mathrm{H}, \mathrm{dd}, \mathrm{J}=1.5 \mathrm{e} 8.0)$ \\
\hline 9 & 128.55 & $7.56(1 \mathrm{H}, \mathrm{t}, \mathrm{J}=7.3, \mathrm{~J}=7.4)$ & 130.5 & $7.52(1 \mathrm{H}, \mathrm{dt}, \mathrm{J}=7.94,1.22)$ & 133.9 & $7.71(1 \mathrm{H}, \mathrm{m})$ or $7.55(1 \mathrm{H}, \mathrm{dt}, \mathrm{J}=1.5 \mathrm{e} 8.0)$ \\
\hline 11 & 127.32 & $8.60(1 \mathrm{H}, \mathrm{dd}, \mathrm{J}=3.05, \mathrm{~J}=10.53)$ & 126.88 & $8.66(1 \mathrm{H}, \mathrm{dt}, \mathrm{J}=7.95)$ & 128.6 & $8.60(1 \mathrm{H}, \mathrm{d}, \mathrm{J}=8.0)$ or $8.56(1 \mathrm{H}, \mathrm{dd}, \mathrm{J}=1.5 \mathrm{e} 8.0)$ \\
\hline $11 \mathrm{a}$ & 132.85 & & 132.34 & & 132.9 & \\
\hline
\end{tabular}

$\mathrm{a}, \mathrm{b} \rightarrow$ Position of $\mathrm{C}$ in order of liriodenine structure. NMR: Nuclear magnetic resonance

$1353\left(\mathrm{IC}_{12} 24.76 \pm 0.56 \mu \mathrm{g} / \mathrm{ml}\right)$, and strain $1138\left(\mathrm{IC}_{12} 7.02 \pm 1.85 \mu \mathrm{g} / \mathrm{ml}\right)$. It means that liriodenine is active both as topoisomerase I inhibitor and topoisomerase II inhibitor. These IC $\mathrm{C}_{12}$ values of isolate were lower than M. champaca bark extract [21] and LLE fractions and mean that isolate more potent than the extract and fractions. Hence, it was clearly defined that liriodenine was an active ingredient of $M$. champaca as an anticancer agent or topoisomerase inhibitor.

This research results reported that based on mechanism-based yeast bioassay M. champaca L. fractions and liriodenine were proved as Type I and Type II topoisomerase inhibitor, whereas other studies only showed liriodenine as topoisomerase II inhibitor. Activity test of liriodenine by in vivo assay using SV40-infected cells and in vitro enzymatic assay reported that liriodenine is a potent inhibitor of topoisomerase II [29]. Computational study of liriodenine by molecular modeling and docking technique reported that liriodenine is the most effective aporphine alkaloids as a novel inhibitor of topoisomerase II [30]. Combination studies by in silico absorption, distribution, metabolism, and excretion toxicology analysis, docking and molecular dynamic simulation of 100 anticancerous alkaloids reported that liriodenine as one of six alkaloids inhibited topoisomerase II [18].

\section{CONCLUSIONS}

Our research revealed that $M$. champaca L. bark fractions active as topoisomerase inhibitor. Isolation from ethyl acetate fraction guided by mechanism-based yeast bioassay carried out liriodenine that active as topoisomerase I inhibitor and topoisomerase II inhibitor.

\section{ACKNOWLEDGMENT}

The authors convey grateful thanks to Professor David G. I. Kingston from Virginia Polytechnic Institute and State University, Mr. Bryan John J. Subong from UP-Diliman, for their correspondences and especially Professor Karlo H. Primavera from UP-Visayas, for advised and the yeast that used in this experiment.

\section{REFERENCES}

1. Heyne K. Indonesian beneficial plants. Tumbuhan Berguna Indonesia. Vol. II. Jakarta: Foundation of Sarana Wana Jaya; 1987. p. 758-64.

2. Kasahara Y, Hemmi S. Medicinal Herbs Indexs in Indonesia. $2^{\text {nd }}$ ed. Jakarta: Eisai Indonesia; 1995. p. 5-6.

3. Khan MR, Kihara M, Omoloso AD. Antimicrobial activity of Michelia champaca. Fitoterapia 2002;73(7-8):744-8.

4. Raja S, Koduru R. A complete profile on Michelia champaca-traditional uses, pharmacological activities and phytoconstituents. Int J Pharm Res Scholars 2014;3(2):496-504.
5. Gupta S, Mehla K, Chauhan D, Nair A. Anti-inflammatory activity of leaves of Michelia champaca investigated on acute inflammation induced rats. Lat Am J Pharm 2011;30(4):819-22.

6. Dhanalaksmi M, Jayasree T, Shaik S. Antiarthritic activity of leaves of Michelia champaca L. By complete Freund's adjuvant. Int J Pharm Technol 2012;4(3):4607-15.

7. Taprial S, Kashyap D, Mehta V, Kumar S, Kumar D. Antifertility effect of hydroalcoholic leaves extract of Michelia champaca L.: An ethnomedicine used by Bhatra women in Chhattisgarh state of India. J Ethnopharmacol. 2013;147:671-5.

8. Shanbhag T, Kodidela S, Shenoy S, Amuthan A, Kurra S. Effect of Michelia champaca Linn flowers on burn wound healing in Wistar rats. Int J Pharm Sci Rev Res 2011;7(2):112-5.

9. Jaishree V, Shabna V. A comparatif study of in vitro antioxidant and DNA damage protection of soxhlet vs microwave assisted extracts of Michelia champaca Linn flowers. Indian J Nat Prod Resour 2011;2(3):330-4.

10. Ananthi T, Chitra M. Screening of in vitro anti-inflammatory activity of Michelia champaca Linn. flower. Asian J Pharm Clin Res 2013;6 Suppl 5:71-2.

11. Ananthi T, Barvin IJ, Chitra M. Antihyperlipidemic activity of Michelia champaca L. in triton WR 1339 induced albino rats. Int J PharmTech Res 2014;6(4):1368-73.

12. Ananthi T, Chitra M, Aruna B. In-vitro anticancer activity of Michelia champaca $\mathrm{L}$. flowers against Ehrlich ascites carcinoma cell line. Int J Pharma Bio Sci 2014;5(4):357-63.

13. Mullaicharam AR, Kumar MS. Effect of Michelia champaca Linn on pylorus ligated rats. J Appl Pharm Sci 2011;01(02):60-4.

14. Monteiro MC, Leptokarydis IH, Silva GH, da Silva VC, Bolzani VS, Young MC, et al. Constituintes quimicos isolados dos caules de Michelia champaca L. (Magnoliaceae). Ecl Quim 2007;32(3):13-8.

15. Jacobson U, Kumar V, Saminathan S. Sesquiterpene lactones from Michelia champaca. Phytochemistry 1995;39(4):839-43.

16. Ahmad H, Mishra A, Gupta R, Saraf SA. Determination of quercetin in Michelia champaca L. (Champa) leaves and stem bark by HPTLC. Int J Pharm Bio Sci 2011;2(4):388-97.

17. Huang CT, Chen SJ, Wu HM, Kang YF, Chen HL, Li WJ, et al. Chemical constituent of the stems of Michelia champaca. Chem Nat Compd 2014;50(6):1047-9.

18. Singh S, Das T, Awasthi M, Pandey VP, Pandey B, Dwivedi UN. DNA topoisomerase directed anti-cancerous alkaloids: ADMET-based screening, molecular docking and dynamics simulation. Biotechnol Appl Biochem 2016;63(1):125-37.

19. Rogojina AT, Li Z, Nitiss KC, Nitiss JL. Using yeast tools to disect the action of anticancer drugs: Mechanism of enzyme inhibition and cell killong by agents targeting DNA topoisomerases. In: Nitiss JL, Heitman J, editors. Yeast as Tool in Cancer Research. Dordrecht: Springer; 2007. p. 409-27.

20. Gunatilaka AA, Kingston DG. DNA-damaging natural product with potential anticancer activity. In: Atta-ur-Rahman, editor. Studies in 
Natural Products Chemistry. Vol. 20. Amsterdam: Elsevier Science BV 1998. p. 457-505.

21. Zuhrotun A, Suganda AG, Wirasutisna KR, Wibowo MS. Anticancer screening of selected Apocynaceae, Simaroubaceae and Magnoliaceae of Indonesian plants using mechanism-based yeast bioassay. Int J Pharm Sci Rev Res 2015;35(2):90-4.

22. Gunatilaka AA, Samaranayake G, Kingston DG, Hoffmann G, Johnson RK. Bioactive ergost-5-ene-3 $\beta, 7 \alpha$-diol derivative from Pseudobersama mossambicensis. J Nat Prod 1992;55(11):1648-54.

23. Subong BJ, Primavera KH. Antitumor potential, anticancer property and phycochemical screening of Padina minor Yamada extracts. Int. J Pharm Sci Rev Res 2012;13(1):34-7.

24. Betina V. Bioautography in paper and thin-layer chromatography and its scope in the antiriotic field. J Chromatogr 1973;78(1):41-51

25. Choma IM, Grzelak EM. Bioautography detection in thin-layer chromatography. J Chromatogr A 2010;12(18):2684-91.

26. de la Cruz Chacón I, González-Esquinca AR. Liriodenine alkaloid in annona diversifolia during early development. Nat Prod Res 2012;26(1):42-9.

27. Skoog DA, Holler FJ, Nieman TA. Principles of Instrumental Analysis. $5^{\text {th }}$ ed. Florida: Harcourt Brace \& Company; 1998.

28. Ogura M, Cordell GA, Fransworth NR. Anticancer sesquiterpene lactones of Michelia compressa (Magnoliaceae). Phytochemistry 1978; 17:957-61.

29. Woo SH, Reynolds MC, Sun NJ, Cassady JM, Snapka RM. Inhibition of topoisomerase II by liriodenine. Biochem Pharmacol (Amsterdam, Neth.) 1997:54:467-73.

30. Nematollahi A, Aminimoghadamfarouj N, Wiart C. Design and modeling studies on liriodenine derivatives as novel topoisomerase II inhibitors. Int J ChemTech Res 2011;3(3):1622-7. 